\title{
Transforming Outstanding Potential in Outstanding Skills by Using Storytelling to Develop Intellectual Abilities of Gifted Students at Risk
}

\author{
Ileana Álvarez-Mendoza, Guadalupe Acle-Tomasini, Rosalinda Lozada-García \\ Faculty of Higher Education Zaragoza, National Autonomous University of Mexico, Mexico City, Mexico \\ Email: alvarez.ileana@gmail.com,gaclet@unam.mx, rosalindalozada@hotmail.com
}

How to cite this paper: Álvarez-Mendoza, I., Acle-Tomasini, G., \& Lozada-García, R. (2018). Transforming Outstanding Potential in Outstanding Skills by Using Storytelling to Develop Intellectual Abilities of Gifted Students at Risk. Creative Education, 9, 1152-1167.

https://doi.org/10.4236/ce.2018.97085

Received: April 3, 2018

Accepted: June 22, 2018

Published: June 25, 2018

Copyright $\odot 2018$ by authors and Scientific Research Publishing Inc. This work is licensed under the Creative Commons Attribution International License (CC BY 4.0).

http://creativecommons.org/licenses/by/4.0/

\begin{abstract}
Gifted children living in vulnerable environments could be at social and educative risk when they do not receive an appropriate instruction with respect to their outstanding potential, particularly in the early years of schooling. The current work considers this rationale to generate an early identification process and implementation of a program that could meet the specific requirements of children who can be targeted with outstanding potential. The purpose of this study was to transform outstanding potential to outstanding intellectual skills of targeted children using an emotional, cognitive and creative enrichment program designed for them based on storytelling activities. In this descriptive non-experimental mixed method design, 7 first and second graders students participate, 4 girls and 3 boys $(\mathrm{M}$-age $=6.28)$. The study was organized in three steps: 1) characterization or the risk/resilience profile of children, using an exploratory and diagnostic assessment; 2) the design and implementation of a cognitive and creative enrichment program based on storytelling activities; and 3) the assessment of changes in intellectual abilities. Results were analyzed quantitatively and qualitatively. The intellectual area showed statistically significant differences in scores for Total IQ, Verbal Comprehension Index and Working Memory Index of children from the initial assessment to the final one, indicating that their capacity to comprehend the active process of the interrelations within and beyond a text as well as to construct a mental representation of its context increased significantly after the program and this constituted an evidence of their intellectual abilities.
\end{abstract}

\section{Keywords}

Outstanding Potential, Outstanding Skills, Cognitive Abilities, Verbal Creativity, 
Enrichment

\section{Introduction}

Children with outstanding skills stand out among their peers since their first years of life because of their high intelligence abilities and maturity; these are boys and girls who tend to score above the standard intelligence tests and have an innate talent for some activities that involve creativity. Intelligence is a feature provided by genetic and influenced by contextual conditions, so different skills will be increased or decreased depending on the environment in which they develop (UNESCO, 2004). Those children who have the contextual support, are the ones that manage to excel in scientific, technological and cultural areas, allowing the contribution to social and economic development of their own countries.

When children receive an appropriate instruction with respect to their proper level of skills and abilities, their real development can be shown. In the case of students who have an outstanding potential, they need learning experiences that motivate them and can constitute a personal challenge. When these children are at social and educative risk and have not this stimulation, it can result in an intellectual inhibition, poor school performance and/or emotional disorders (UNESCO, 2004). On the other hand, the lack of educational interventions from an early age can generate poor study habits, a lack of motivation and a reduction of new neural connections specially from 7 to 10 years old. A child with a genetic potential, without a stimulating environment, will not develop their full potential. That is why early identification of outstanding potential in early years of life is so important. This allows to meet their special educational needs since the first grades of elementary school.

This paper will argue both outstanding skills as outstanding potential, considering the parameters set by the Unit Nations Organization for Education, Science and Culture, UNESCO (2004) that considers the outstanding skills as those that have already been developed and evidenced, and at the contrary the outstanding potential is that one that has not yet been acquired or demonstrated. It means that the subject has the potential to develop or show their outstanding ability, but because one or more risk factors has not been able to reveal them in their plans of action; the latter becomes relevant since the outstanding skills are taken as a construct with an evolutionary character, in which the potential can be changed with a good educational intervention.

Considering the aforementioned, to convert the outstanding potential into outstanding skills, it is indispensable to provide educational opportunities in the immediate context in which the student develops daily. The current work considers this rationale to generate an identification process and the implementation of a program that meets the specific requirements of the children who are targeted with outstanding potential. The ecological risk/resilience model 
(Acle-Tomasini, 2012; Acle-Tomasini, Martínez-Basurto, \& Lozada-García, 2016) gives the opportunity to understand, detect and give an individualized attention for children analyzing their interactions with the family, school and community, the immediate contexts in which they interact.

At Mexico it is reported that $25 \%$ of students who are served by Special Education Services are children with outstanding skills (Secretaría de Educación Pública, 2012); however, many children who might qualify under this category, because the lack of clarity of the identification process, especially in schools located in remote and/or underserved areas, are not included in official programs and therefore they lose the opportunity to develop higher levels of performance. It is in this context that to provide education to outstanding students becomes relevant, since it is the population that has the capacity to become specialized and productive in scientific, technological and creative fields

(Antonio-Cañongo, Acle-Tomasini, Martínez-Basurto, \& Ordaz-Villegas, 2015; Valdés, Sánchez-Escobedo, \& Yáñez, 2013).

It should be emphasized that in Mexico, the issue of social inequality is still very strong in particular in the educational context, this work was developed in a public elementary school located in the Iztapalapa suburb, east of Mexico City; which has experienced a rapid growth in its population (Arango \& Lara, 2005), that has a high percentage of unemployed population, it is a zone that has the highest percentage of illiteracy in Mexico City with 27.5\% (United Nations Children's Fund, 2006), and its population earns on average just over 1,654 dollars annually, not having enough health services to meet their demands (Rosales, Montero, \& Melgoza, 2005).

In the other hand, the intervention program proposed was based on the storybooks, considered as the main tools because the processes involved in them as the reading understanding, creating and writing stories; to use the storytelling and storybooks could be reading effective pedagogical strategies that can be used to improve student's competencies in different areas (Miller \& Pennycuff, 2008). When children first learn to read, teachers and students focus on the physical features of writing, subsequently they need to understand the meaning form words and how they function in a sentence, paragraph or text. It involves a cognitive activity to understand the explanations inside the text itself, children must construct a mental representation of its contents and comprehend in an active way the interrelations within and beyond the text. In this activity inferences are activated and the information obtained from the text is related to the previous information and knowledge of children in order to coordinate several skills to get the whole process of decoding the words and the syntactic and pragmatic construction process and to assimilate the global structure and main idea of the text as a whole (Katzenberg, 2004; Berman \& Dorit, 2009; Kaplan, 2013).

Human beings are natural storytellers, in most civilizations evidence of storytelling has been found as a way of understanding the world and ourselves, they help people to understand their place in the world, construct their identity and 
make connections between social and internal world. Schools are important places for children to think about who they are (Barton \& Baguley, 2014). In academic context read-aloud storybooks, involves an sequentially organized and dynamic events that allows the children to track the temporal and spatial circumstances surrounding the story, it has been demonstrated the benefits for children including improved vocabulary, engagement with text, comprehension of print concepts, and attitudes about reading (Chow \& Mcbride-Chang, 2003; Biemiller \& Boote, 2006; Mira \& Schwanenflugel, 2013). Findings indicate, that children become more efficient at encoding complete representations of narrative events with age; they can recognize protagonists' goals and intentions by age 8 ; they understand casual relations between the episodes of a story around age 10 , it is not until age 14 years that they achieve an integrative understanding of the main causal-motivational notions interrelating the events. Engaging in storybook reading activities is a way to motivate children to read and write, it is a strategy that relies on both the listener and the teller utilizing social elements of language contributing to interactions and collaboration with others (Teale, 2003).

Several studies have been conducted regarding the effectiveness of the use of storytelling as a pedagogical strategy in preschool children (Linhui, Zhou, Baogen, \& Xiaomei, 2012; Schickedanz \& Collins, 2012; Schwarz et al., 2015; Van Horn \& Kan, 2016), in children with language impairments (Justice, Skibbe, McGinty, Piasta, \& Petrill, 2011; Allena, Oetting, \& Tyler, 2013; Maul \& Ambler, 2014), and bilingual children (Gillanders \& Castro, 2011; Wessels, 2014; Herzig \& Malzkuhn, 2015). The main results showed the benefits of instruction regarding greater comprehension, better identification of the setting, moral and characters of the stories, greater use of the visual imagination and literacy skills. Representation of the stories learned from storybooks allow children to participate in a role providing them with the opportunity to become someone else and express things they may not normally say as themselves; stories are an excellent resource to use as the basis of drama activities, where students works with elements of the plot and characters, activity that focuses on group interaction and draws on a range of experiences that enrich personal feelings of individuals inside the group However, despite these findings and the vast amount of studies about storybooks and reading aloud benefits in school context, research on the usage of these techniques in young high ability students is scare. Acle-Tomasini et al. (2016) have underlined the high incidence of children with special educational needs living at social and educative vulnerable situations, in their research the main findings after the initial assessment of 1022 first and second graders of elementary school revealed an average of 52\% students at educative risk. Using the WISC-IV, $23.35 \%$ of them showed an outstanding intellectual potential. The authors highlighted that if their outstanding potential is not identified neither stimulated in the early years of school they could lose the opportunity to develop higher levels of performance. Evidence-based special education practices have 
proved the importance of defining the problem, selecting and applying strategies to solve it, and assessing outcomes. The following research questions guided this study:

1) How the outstanding potential of gifted children at educative risk can be converted in outstanding intellectual skills by using an enrichment program based in storytelling activities?

2) What kind of achievement did these students show in their intellectual and cognitive abilities after the implementation of the enrichment program?

\section{Method}

\subsection{General Objectives}

1) To transform outstanding potential into outstanding intellectual skills in gifted children at educative risk using an emotional, cognitive and creative enrichment program based storytelling activities.

2) To assess changes in the intellectual and cognitive abilities after the application of the intervention program.

\subsection{Study Design}

A sequential explanatory design (Creswell, 2015) was employed, quantitative data was collected first and then qualitative information to enhance quantitative results.

\subsection{Type of Study}

A non-experimental design is proposed, it does not involve significant comparison groups or conditions that did not receive treatment induced actively by the researcher (Cook et al., 2008). It was organized in three phases: 1) An initial assessment to create a characterization of the risk/resilience profile of targeted children with outstanding potential. 2) The intervention phase based in the implementation of the emotional, cognitive and creative enrichment program based in storytelling activities; and 3) The final assessment to evaluate the effects of the program, particularly of outstanding intellectual skills.

\subsection{Participants}

The sample consisted of 7 students, 4 girls and 3 boys ( $\mathrm{M}_{\text {age }}=6.5$ years), who were chosen based on their academic performance, teacher recommendation and IQ Total obtained in the WISC-IV (Table 1).

It must be noted that these 7 children were reported also by their teachers as students with an outstanding creativity in school activities and homework, with an engagement level higher than their mates.

\subsection{Instrument}

Wechsler Intelligence Scale for Children (WISC-IV Wechsler, 2007) was applied. It is an instrument that assesses global cognitive ability and four specific 
Table 1. Characteristic of participants referred to sex, grade and IQ Total of the initial assessment.

\begin{tabular}{cccc}
\hline & Sex & Grade & IQ Total \\
\hline Student A & F & $1^{\circ}$ & 93 \\
Student B & M & $1^{\circ}$ & 108 \\
Student C & M & $1^{\circ}$ & 112 \\
Student D & F & $1^{\circ}$ & 106 \\
Student E & M & $2^{\circ}$ & 113 \\
Student F & F & $2^{\circ}$ & 105 \\
Student G & F & $2^{\circ}$ & 108 \\
\hline
\end{tabular}

domains of intelligence, it allows a precise and deep cognitive analysis of the involved process, consists of 15 tests (10 essential and five complementary) by which a profile of scalar scores are obtained, a total score and four indices, explained below: 1) Verbal Comprehension Index, in which the application of verbal skills and information to solve new problems and the ability to process verbal information and the capacity to carry out thinking into words are evaluated. 2) Visual Spatial Index: where the perceptual organization, the ability to think in terms of visual images and manipulating them with fluidity and flexibility, and the ability to interpret or visually organize the material collected within a limit of time are evaluated. 3) Working Memory Index: in which the capacity to maintain attention, the short-term memory and the numerical ability are measured. 4) Processing Speed Index: where you can evaluate the level of perceptual discrimination, the speed of mental operation, the psychomotor speed, the attention, the concentration, the short-term visual memory, the visual-motor coordination and the cognitive flexibility. This test compares the performance in the various indexes and subtests identify strengths and weaknesses and an analysis processing. The items are grouped growing and orderly according to their level of difficulty, the purpose is to know the IQ of children of school age from 6 to 16 years; is an individual time test whose application requires 60 to $90 \mathrm{mi}$ nutes. Reliability coefficients for total IQ is 0.95 while for the subtests reliability coefficients ranged around 0.83 with a minimum of 0.72 and a maximum of 0.91

\subsection{Context and Setting}

The study was conducted in a public elementary school with a 4 hours schedule from 8:00 a.m. to 12:30 p.m. This school is situated in the Iztapalapa suburb of Mexico City, considered as one of the most populated zone with the highest illiteracy, unemployment, and crime rates (Arango \& Lara, 2005). It is considered as a marginalized zone.

\subsection{Procedure}

1) School officials, parents, and students identified as outstanding potential 
were informed about the purposes of the study, before administration parents were given an individual informed consent form, which they read and signed after. An emphasis was made on confidentiality of data, respondent anonymity and the science-promotion purposes of collection. Children were given their assent.

2) An exploratory evaluation with the WISC-IV test was applied to $73 \mathrm{stu}$ dents in first and second grade of an elementary public school, seven of them were targeted as children with outstanding potential and subsequently it was held a diagnostic evaluation with complementary tests, to determine their individual characteristics and performance. An ecological validity was gathered of their teachers who approved their inclusion in the enrichment program considering their higher achievement in school and homework activities in contrast with their mates of the same age and grade.

3) The intervention program design was focused on the skills in which children with outstanding potential had slight difficulties or which had skills to improve, founding as priorities: social-emotional area, the language and creativity. From this information, a descriptive schedule of the program was designed, including the overall objective setting blocks required to organize content, specific objectives and the number of sessions of each block (Table 2). The program was implemented for 10 months, and consisted of 24 sessions lasting 60 minutes each.

Table 2. Descriptive schedule of the emotional, creative and cognitive enrichment program.

\section{General objective}

To enrich the development of cognitive and socio-emotional creative processes in children with outstanding potential through play and storybook telling.

\begin{tabular}{|c|c|c|c|}
\hline Block & Objective & Skills to work & No. sessions \\
\hline $\begin{array}{l}1 \\
\text { Cooperative } \\
\text { Game }\end{array}$ & $\begin{array}{l}\text { To promote the positive interaction and participation of children inside the } \\
\text { group (increasing facilitators of socialization behaviors, and recognizing the } \\
\text { functionality of these skills inside and outside the intervention program) } \\
\text { through play cooperative and reflection of stories. }\end{array}$ & $\begin{array}{l}\text { Social: } \\
\text {-Group cohesion }\end{array}$ & 6 weekly sessions \\
\hline $\begin{array}{l}2 \\
\text { Tale }\end{array}$ & $\begin{array}{l}\text { To enhance linguistic organization skills through the storytelling to improve } \\
\text { the concept formation, the moral judgment and the abstract part of the } \\
\text { language through hearing, structuring, and creating stories, as well as cha- } \\
\text { racter analysis. }\end{array}$ & $\begin{array}{l}\text { Cognitive: } \\
\text {-Linguistic organization } \\
\text {-Reading } \\
\text {-Writing } \\
\text {-Structuring Emotional: } \\
\text {-Moral judgment }\end{array}$ & 6 , weekly sessions \\
\hline $\begin{array}{l}3 \\
\text { Emotional } \\
\text { development }\end{array}$ & $\begin{array}{l}\text { To provide strategies that promote the individual and emotional develop- } \\
\text { ment of children, improve self-concept, recognition and expression of emo- } \\
\text { tions in themselves and in others, as well as the self regulation of emotions } \\
\text { through play experiences, play and analysis of stories. }\end{array}$ & $\begin{array}{l}\text { Emotional: } \\
\text {-Self concept } \\
\text {-Self esteem } \\
\text {-Recognition and management } \\
\text { of emotions }\end{array}$ & 6, weekly sessions \\
\hline $\begin{array}{l}4 \\
\text { Creativity }\end{array}$ & $\begin{array}{l}\text { To encourage verbal and graphic-figural creativity using artistic and verbal } \\
\text { games. }\end{array}$ & $\begin{array}{l}\text { Creativity: } \\
\text {-Verbal creativity } \\
\text { - Graphic-figural creativity }\end{array}$ & 6 , weekly sessions \\
\hline
\end{tabular}


4) After the intervention the WISC-IV test was reapplied 20 months after the first application. Its properties let to assesses global cognitive ability as well as four specific domains of intelligence related to involved process in the verbal and graphic activities implemented particularly in the storytelling strategies. In addition, children's verbalizations at ecological outcome validation meetings were gathered.

\subsection{Analysis of Results}

Obtained data were quantitatively and qualitatively analyzed. Data from the WISC-IV test for children were analyzed using the SPSS version 20 software. To identify statistically significant differences between the scores of the WISC-IV test after the intervention program, the statistical nonparametric Wilcoxon test was used taking into consideration the Total IQ, and the analyses of each index separately. Data collected from comments made by children of the implemented program were qualitatively analyzed.

\section{Results}

\subsection{Assessment of Changes in Intellectual and Cognitive Abilities}

It was observed that the scores for Total IQ of children with outstanding potential had a statistically significant difference $(z=2371, p=0.018)$ from the initial assessment $(M=106.43)$ to the final one $(M=125.86)$, indicating that intellectual and cognitive abilities of students increased significantly after the program. Furthermore, WISC-IV index of the test were analyzed separately, the results are presented in Table 3, in which it can be observed statistically significant increases for Verbal Comprehension Index $(z=2.371, p<0.05)$ and for the Working Memory Index $(\mathrm{z}=2.371, p<0.05)$. These results suggest that the program in the verbal area favored the skills training of verbal concepts, expression of relationships between concepts, wealth and precision in the definition of the words, social understanding, practical judgment, foreground and verbal agility and execution; as for the memory area it favored the retention, storage and mental operation of the new information to transform and generate new information.

Table 3. Comparison of the average scores of verbal comprehension, perceptual reasoning, working memory, processing speed and total IQ before and after implementation of the intervention program.

\begin{tabular}{cccc}
\hline \multirow{2}{*}{ Index } & \multicolumn{2}{c}{ Scores } & \multirow{2}{*}{ Wilcoxon test } \\
\cline { 2 - 3 } & Initial Assessment & Final Assessment & \\
\hline Verbal Comprehension & 97.86 & 127.43 & $p=0.018, \mathrm{z}=2.371$ \\
Visual Spatial & 117.5 & 120.7 & $p=0.018, \mathrm{z}=2.371$ \\
Working Memory & 97.86 & 118.7 & $p=0.600, \mathrm{z}=0.524$ \\
Processing Speed & 103.8 & 110.5 & $p=0.018, \mathrm{z}=2.371$ \\
Total IQ & 106.43 & 125.86 & $p=0.596, \mathrm{z}=0.530$ \\
\hline
\end{tabular}


Furthermore, it was conducted an analysis of observed changes in subtests for each index, Table 4 shows the results.

As it can be seen in the Verbal Comprehension Index, a statistically significant increase was obtained in all the subtests: Similarities $(z=2.226, p<0.05)$ which analyzes the ability to abstract and generalize from two given concepts; Vocabulary $(\mathrm{z}=2.375, p<0.05)$ subtest that refers to the lexical knowledge, conceptual precision and expressive verbal ability; Comprehension $(\mathrm{z}=2.371, p<0.05)$ which measures the reasoning and social judgment against solving everyday problems; Information $(\mathrm{z}=2.060, p<0.05)$ that refers to the ability to acquire, store and retrieve knowledge previously acquired; and Word Reasoning $(\mathrm{z}=$ 2.032, $p<0.05$ ), which measures the ability to integrate information, generate alternative concepts and condense information. This result highlights that all the students change in a significant way their verbal understanding ability, thus it can be assumed this will an effect of the storytelling activities of the program.

In the case of the Visual Spatial Index, we observed a statistically significant difference only in the subtest of Picture Competition $(\mathrm{z}=2.023, p<0.05)$ which refers to the ability of the perceptual recognition and organization of visual information when time is control. For the Working Memory Index statistically significant changes were observed in all their subtests; in the Digit Span $(z=$ $2.388, p<0.05)$ related with memory processes, specifically in the skills of sequencing, planning, and cognitive flexibility; in the Letter-Number Sequencing $(\mathrm{z}=2.388, p<0.05)$, which refers to the ability to retain and combine two types of information, organize it and develop an organized set; and Numeracy $(z=$

Table 4. Average index scores of verbal comprehension, perceptual reasoning, working memory and processing speed before and after the implementation of the program.

\begin{tabular}{|c|c|c|c|c|c|c|}
\hline \multirow{2}{*}{ Index } & \multirow{2}{*}{ Subtest } & \multicolumn{2}{|c|}{ Initial Assessment } & \multicolumn{2}{|c|}{ Final Assessment } & \multirow{2}{*}{ Wilcoxon } \\
\hline & & $\mathbf{M}$ & D.E. & $\mathbf{M}$ & D.E & \\
\hline \multirow{5}{*}{ Verbal Comprehension } & Similarities & 7.86 & 2.795 & 14.14 & 3.237 & $p=0.026, \mathrm{z}=-2.226$ \\
\hline & Vocabulary & 11.71 & 2.430 & 15.29 & 1.799 & $p=0.018, \mathrm{z}=-2.375$ \\
\hline & Comprehension & 9.71 & 2.430 & 14.43 & 2.070 & $p=0.018, z=-2.371$ \\
\hline & Information & 10.00 & 1.528 & 11.14 & 1.069 & $p=0.039, \mathrm{z}=-2.060$ \\
\hline & Word Reasoning & 8.57 & 2.637 & 11.86 & 3.579 & $p=0.042, \mathrm{z}=-2.032$ \\
\hline \multirow{4}{*}{ Visual Spatial } & Block Design & 11.71 & 1.704 & 13.00 & 3.367 & $p=0.279, \mathrm{z}=-1.084$ \\
\hline & Picture Concepts & 13.86 & 2.676 & 14.43 & 2.370 & $p=0.234, \mathrm{z}=-1.190$ \\
\hline & Matrix Reasoning & 12.86 & 3.078 & 12.57 & 2.637 & $p=0.892, \mathrm{z}=-0.135$ \\
\hline & Picture Completion & 12.43 & 3.690 & 16.71 & 2.289 & $p=\mathbf{0 . 0 4 3 , z}=-2.023$ \\
\hline \multirow{3}{*}{ Working Memory } & Digit Span & 9.86 & 1.676 & 13.29 & 2.984 & $p=0.017, \mathrm{z}=-2.388$ \\
\hline & Letter-Number Sequencing & 9.57 & 2.149 & 13.57 & 1.618 & $p=0.017, \mathrm{z}=-2.388$ \\
\hline & Arithmetic & 11.57 & 1.512 & 14.86 & 2.116 & $p=0.045, \mathrm{z}=-2.200$ \\
\hline \multirow{2}{*}{ Processing Speed } & Coding & 10.86 & 1.345 & 12.00 & 3.215 & $p=0.670, \mathrm{z}=-0.426$ \\
\hline & Symbol Search & 10.43 & 2.070 & 11.86 & 2.673 & $p=0.336, \mathrm{z}=-0.962$ \\
\hline
\end{tabular}


2.371, $p<0.05$ ), which refers to the ability of numerical reasoning, agility in management and reorganization of information, attention and short term memory. In the Processing Speed Index, no statistically significant changes were observed. To carry out an intra-subject analysis, a comparison was made for the individual scores of children in Total IQ before and after the program implementation (Table 5).

Using the analysis of repeated measurements to identify changes intra-subject between the initial and final assessment, statistical significative differences were found in six of the students in Total IQ $\left.\left(\mathrm{F}_{1,6}\right)=79.382, p<0.001\right)$ as well in the Verbal Comprehension Index $\left.\left(\mathrm{F}_{1,6}\right)=216.409, p<0.001\right)$ and the Working Memory Index $\left.\left(\mathrm{F}_{1,6}\right)=22.422, p<0.003\right)$.

Table 6 shows the changes in level scores before and after the implementation of the program. As for the Verbal Comprehension Index, before the program all students were in the range of rated "Average", at the end, three of them moved to the rank of "Very High" and three to the "Superior". The Visual Spatial Index showed no significant changes since it was the area of greatest development before program implementation, two of the children changed to a superior and four remained in the same category, while one of them did in reverse. As for the

Table 5. Individual distribution of Total IQ scores of children with outstanding potential.

\begin{tabular}{ccc}
\hline Student & Initial Assessment Total IQ scores & Final Assessment Total IQ scores \\
\hline Student A & 93 & 108 \\
Student B & 108 & 126 \\
Student C & 112 & 138 \\
Student D & 106 & 127 \\
Student E & 113 & 123 \\
Student F & 105 & 125 \\
Student G & 108 & 134 \\
\hline
\end{tabular}

Table 6. Individual changes in scores before and after the implementation of the program.

\begin{tabular}{lcccccccccc}
\hline & \multicolumn{2}{c}{$\begin{array}{c}\text { Verbal } \\
\text { Comprehension }\end{array}$} & Visual Spatial & $\begin{array}{c}\text { Working } \\
\text { Memory }\end{array}$ & $\begin{array}{c}\text { Processing } \\
\text { Speed }\end{array}$ & IQ Total \\
\cline { 2 - 9 } & Before & After & Before & After & Before & After & Before & After & Before & After \\
\hline Student A & 83 & 110 & 102 & 96 & 97 & 126 & 103 & 91 & 93 & 108 \\
Student B & 91 & 124 & 117 & 129 & 102 & 110 & 118 & 115 & 108 & 126 \\
Student C & 110 & 140 & 119 & 141 & 94 & 123 & 109 & 109 & 112 & 138 \\
Student D & 102 & 124 & 110 & 108 & 110 & 120 & 91 & 136 & 106 & 127 \\
Student E & 104 & 132 & 131 & 123 & 97 & 110 & 100 & 97 & 113 & 123 \\
Student F & 96 & 124 & 123 & 123 & 86 & 104 & 106 & 123 & 105 & 125 \\
Student G & 99 & 138 & 121 & 125 & 99 & 138 & 100 & 103 & 108 & 134 \\
\hline
\end{tabular}


Working Memory Index, three students remained in the "Average" rating, three of them went from "Average" to "Higher" and one step from "Average" to "Very High". In the case of the Processing Speed Index, four children remained in the rating of "Average" one in the "Average High", and two of the students changed the range "Average" to the ranks of "Superior" and "Very Superior".

As for the Total IQ, changes were found in six of the seven children who participated in the program, two children currently have more than 130 IQ which classifies them in the rank of "Very High", four of them they ranked in the rank of "Superior" and remained in the "average" range. These data show that there was indicative of increased intellectual and cognitive skills of children after the implementation of the program.

\subsection{Children Comments}

At the end of the intervention program, children said they were very happy to participate in the sessions with the psychologist, they said they could learn new things in a funny way, they felt very well assisting to the sessions and feeling that they belong to a new team at school with whom they could count and get support. In Table 7, examples of the verbalizations made by children are displayed.

This evidence provides data to the social validation that children give to the program, appreciating its usefulness and benefits.

\section{Discussion}

The findings here exposed highlights the way in which the outstanding potential can be transformed in outstanding intellectual and cognitive skills of gifted children at social and educative risk, not only because they were identified in the early years of the elementary school but because it was possible to conduct with them an enrichment emotional, creative and cognitive program based in storytelling activities. The results of this program may indicate that when a deep analysis on the child and their role in the social sphere in which it operates is done, the results can be very flattering, and although the program was given weight to multiple areas (emotional, cognitive and creative). Particularly, in the intellectual area which is the focus of this paper, it was found statistically

Table 7. Comments made by some of the children after the intervention program.

\begin{tabular}{l}
\hline Children verbalizations after the implementation of the program \\
\hline Student B "This program taught me that we have to respect people, you were very good to us" \\
Student D "I liked all the activities we did, I liked that you came and worked together with all of \\
us, you left something very special, now I have more friends. Thank you very much" \\
"You taught me to speak before fighting. To know that I am strong but I do not need \\
to fight fiscally, everything was fun; I also like doing things with my hands and to \\
draw" \\
"I liked you coming and teaching us new things, you left us a lesson, I really liked \\
coming and having fun with everyone"
\end{tabular}


significant differences, it was observed that the scores for Total IQ of children with outstanding potential had a statistically significant difference from the initial assessment to the final one, indicating that their intellectual and cognitive abilities increased significantly after the program and these was revealed in evident outstanding intellectual skills considering the parameters set by UNESCO (2004).

As it was stated by Berman and Dorit (2009), Kaplan (2013) and Katzenberg (2004), storytelling strategies involve a cognitive demanding activity to understand the explanations inside the text itself since children must construct a mental representation of its contents and comprehend the active process of the interrelations within and beyond the text. In this way the different activities performed by children during the intervention program as the cooperative game, linguistic organization skills to tell stories, reading and writing them enhancing a verbal creativity could contribute to the statically significative differences observed from the initial assessment to the final one in the Verbal Comprehension Index, the Working Memory Index and the Visual Spatial Index. In this way to convert the outstanding potential into outstanding skills it is indispensable to provide educational opportunities in the immediate context in which the student develops daily, if they are at educative and social risk. As it was stated by Brouillette (2010), Kieler (2010) and Teale (2003) engaging children in storybook reading activities motivate them to read and write, children verbalizations about the activities in which they participated showed the its importance.

Although we recognize that reported changes in this study could not be only attributed to the enrichment program, because participants are children in a maturity process and in a learning situation at school, it can be underlined that early screening of outstanding potential with its consequent stimulation, can contribute to the empowerment of the outstanding potential and skills of gifted children, especially if one observes they are living in vulnerable social and educational situations. The constant communication with their parents and teachers was a protective factor in all the implemented procedures.

Nevertheless, to provide a comprehensive care, it is necessary that professionals in special education, see children as being immersed in different contexts, including the family, school and society in which they live. To do this, first it is important to recognize the individuality of each child and the unique and complex circumstances of the environment in which he develops; the interaction starts from birth and continues over time, continually changing and modifying (Kirk, Gallagher, Anastasiow \& Coleman, 2006). Considering that this work founded on the ecological risk/resilience model in special education (Acle-Tomasini, 2012) highlights the relevance to analyses risk and protective factors to implement a specific assessment/intervention program focused on altering the way students interact with different people and within different contexts, to promote a better academic achievement and educational inclusion. The emotional, cognitive and creative program showed that it is possible at early years of schooling to improve the educational and social performance of child- 
ren living in social vulnerable environments assisting at schools situated in marginalized areas of Mexico City.

Furthermore, enrichment programs founded in the model proved its functionality in transforming outstanding potential in outstanding intellectual skills of gifted children in different school environments where collaborative work with parents and teachers has been realized (Antonio-Cañongo, 2014; Chavez, Zacatelco, \& Acle, 2009; Durán-Fonseca, 2016; Romero-Godinez, 2012; Zacatelco, Hernández, \& Acle, 2012). Working from this type of model, allowed a comprehensive assessment that yielded a lot of information to make informed decisions about intervention programs from which the educational needs of children were addressed; also permitted to meet the immediate contexts that influence the behavior and development of student skills to foster better interactions between them that reverberated protective factors in the development of gifted children at social and educative risk.

\section{Limitations and Directions for Future Research}

An important contribution of the study lies in the opportunity that we can give to gifted students living at social and educative risk (Burney \& Beilke, 2008), when an early assessment of their outstanding potential is made in the early years of schooling, not only with formal test but also taking in account teacher's perceptions of their higher performance at school and homework activities, and then using an enrichment program based on storytelling activities to reveal their outstanding intellectual development and cognitive skills. These findings have implications for the allocation of resources for emotional, creative and cognitive programs for gifted children of low income families.

Nevertheless, it must be pointed out that a main limitation of the study is related with the size of the sample, so caution must be taken in generalizing the findings. Although the design and implementation of the enrichment program displayed positives outcomes for the seven children identified with outstanding intellectual potential, and allowed us to prove the benefits that they reached with this kind of programs, it will be relevant in the future to set up specific parameters of each one of the emotional, cognitive and creative abilities involved in the storytelling program. These parameters would let us to make a specific evaluation of different abilities involved before and after the program implementation, so this will permit us to acknowledge with more accuracy the produced changes and to investigate the relationship between them and the outstanding intellectual skills related to storytelling strategies.

\section{Acknowledgements}

G.A.T. thanks to the Programa de Apoyo a Proyectos de Investigación e Innovación Tecnológica (PAPIIT) IN303615 (Support for Research and Innovation Projects Program IN303615) for supporting this research.

I.A.M. thanks for the scholarship received during the master studies in the 
Maestría en Psicología de la Universidad Nacional Autónoma de México (Master Program in Psychology, National Autonomous University of México), of the

Consejo Nacional de Ciencia y Tecnología (National Council of Science and Technology).

\section{References}

Acle-Tomasini, G. (2012). Resiliencia en educación especial: una experiencia en la escuela regular [Resilience in Special Education. An Experience in Elementary School]. GEDISA-UNAM-FES ZARAGOZA: Barcelona, España.

Acle-Tomasini, G., Martínez-Basurto, M. L., \& Lozada-García, R. (2016). Bridging the Gap between Theory and Practice: Ecological Risk/Resilience Model Contributions to Special Education. Creative Education, 7, 1093-1110.

https://doi.org/10.4236/ce.2016.77114

Allena, M. M., Oetting, J., \& Tyler, A. (2013). Intervention Efficacy and Intensity for Children with Speech Sound Disorder. Journal of Speech, Language \& Hearing Research, 56, 865-877. https://doi.org/10.1044/1092-4388(2012/11-0076)

Antonio-Cañongo, A. (2014). Enriquecimiento cognitivo y creativo: Factor protector para los alumnos con aptitudes sobresalientes en zonas marginadas [Cognitive and Creative Enrichment: Protective Factor for Gifted Students in Disadvantaged Areas]. Unpublished Master's Thesis, Mexico: Universidad Nacional Autónoma de México.

Antonio-Cañongo, A., Acle-Tomasini, G., Martínez-Basurto, M. L., \& Ordaz-Villegas, G. (2015). Social Validity of a Creative and Cognitive Enrichment Program for Gifted Children. Creative Education, 6, 1667-1679. https://doi.org/10.4236/ce.2015.615168

Arango, A., \& Lara, C. (2005). Delegación Iztapalapa: Perfil Sociodemográfico. Análisis sobre la violencia social en la Delegación Iztapalapa (Iztapalapa Municipality: Socio-Demographic Profile. An Analysis of the Social Violence in the Iztapalapa Municipality]. Instituto Ciudadano de Estudios Sobre la Inseguridad A.C.: México.

Barton, G., \& Baguley, M. (2014). Learning through Story: A Collaborative, Multimodal Arts Approach. English Teaching: Practice and Critique, 13, 93-112. https://search.proquest.com/openview/b09a8ed03e092550ccd76985b8f576ca/1?pq-orig $\underline{\text { site }=\text { gscholar \&cbl }=736343}$

Berman, R., \& Dorit, R. (2009). Becoming a Literate Language User: Oral and Written Text Construction across Adolescence. In D. R. Olson, \& N. Torrance (Eds.), The Cambridge Handbook of Literacy (pp. 92-111). Cambridge, UK: Cambridge University Press.

Biemiller, A., \& Boote, C. (2006). An Effective Method for Building Meaning Vocabulary in Primary Grades. Journal of Educational Psychology, 98, 44-62. https://doi.org/10.1037/0022-0663.98.1.44

Brouillette, L. (2010). How the Arts Help Children to Create Healthy Social Scripts: Exploring the Perceptions of Elementary Teachers. Arts Education Policy Review, 111, 16-24. https://eric.ed.gov/?id=EJ860520

Burney, V. H., \& Beilke, J. R. (2008). The Constraints of Poverty on High Achievement. Journal for the Education of the Gifted, 31, 295-321. http://journals.sagepub.com/doi/abs/10.4219/jeg-2008-771

Chavez-Soto, B. I., Zacatelco-Ramírez, F., \& Acle-Tomasini, G. (2009). Programa de enriquecimiento de la creatividad para alumnos sobresalientes. Electronic Journal of Research in Educational Psychology, 7, 849-876.

http://investigacion-psicopedagogica.org/revista/new/ContadorArticulo.php?339 
Chow, W.-Y. B., \& Mcbride-Chang, C. (2003). Promoting Language and Literacy Development through Parent-Child Reading in Hong Kong Preschoolers. Early Education \& Development, 14, 233-248. https://doi.org/10.1207/s15566935eed1402_6

Cook, L., Cook, B., Landrum, T., \& Tankersley, M. (2008). Examining the Role of Group Experimental Research in Establishing Evidenced-Based Practices. Intervention in School and Clinic, 44, 76-82. https://doi.org/10.1177/1053451208324504

Creswell, J. (2015). Educational Research: Planning, Conducting, and Evaluating Quantitative and Qualitative Research. New York: Pearson.

Durán-Fonseca, T. D. D. (2016). Validación social de un programa de enriquecimiento para alumnos sobresalientes bajo el modelo de riesgo/resiliencia (Social Validity of an Enrichment Program for Gifted Students Based on the Risk/Resilience Model). Unpublished Master's Thesis, Universidad Nacional Autónoma de México: México.

Gillanders, C., \& Castro, D. C. (2011). Storybook Reading for Young Dual Language Learners. Young Children, 66, 91-95.

https://source.ucdenver.edu/cgi/viewcontent.cgi?referer=https://www.google.com.mx/ \&httpsredir $=1 \&$ articl $=1027 \&$ context $=$ ece_publications

Herzig, M., \& Malzkuhn, M. (2015). Bilingual Storybook Apps: An Interactive Reading Experience for Children. Odyssey: New Directions in Deaf Education, 16, 40-44. https://eric.ed.gov/?id=EJ1064219

Justice, L. M., Skibbe, L. E., McGinty, A. S., Piasta, S. B., \& Petrill, S. (2011). Feasibility, Efficacy, and Social Validity of Home-Based Storybook Reading Intervention for Children with Language Impairment. Journal of Speech, Language, and Hearing Research, 54, 523-538. https://jslhr.pubs.asha.org/article.aspx?articleid=1784187 https://doi.org/10.1044/1092-4388(2010/09-0151)

Kaplan, D. (2013). Development of Reading Comprehension from Middle Childhood to Adolescence. Written Language \& Literacy, 16, 208-240.

https://benjamins.com/\#catalog/journals/wll.16.2.04kap/details https://doi.org/10.1075/wll.16.2.04kap

Katzenberg, I. (2004). The Superstructure of Written Expository Texts: A Developmental Perspective. In R., Dorit, \& B.-Z. S., Hava (Eds.), Perspectives on Language and Language Development (pp. 327-336). Dordrecht: Kluwer Academic.

Kieler, L. (2010). Trials in Using Digital Storytelling Effectively with the Gifted. Gifted Child Today, 33, 48-52. https://doi.org/10.1177/107621751003300311 http://journals.sagepub.com/doi/abs/10.1177/107621751003300311

Kirk, S., Gallagher, J., Anastasiow, N., \& Coleman, M. R. (2006). Educating Exceptional Children. Boston, NY: Houghton Mifflin Company.

Linhui, L., Zhou, J., Baogen, L., \& Xiaomei, G. (2012). Chinese Preschool Children's Comprehension of a Picture Storybook. Chinese Language \& Discourse, 3, 109-127. http://www.jbeplatform.com/content/journals/10.1075/cld.3.1.06li

Maul, C. A., \& Ambler, K. L. (2014). Embedding Language Therapy in Dialogic Reading to Teach Morphologic Structures to Children with Language Disorders. Communication Disorders Quarterly, 35, 237-247. https://doi.org/10.1177/1525740114525657 http://journals.sagepub.com/doi/full/10.1177/1525740114525657

Miller, S., \& Pennycuff, L. (2008). The Power of Story: Using Storytelling to Improve Literacy Learning. Journal of Cross Disciplinary Perspectives in Education, 1, 36-43. http://wmpeople.wm.edu/asset/index/mxtsch/storytelling

Mira, W. A., \& Schwanenflugel, P. J. (2013). The Impact of Reading Expressiveness on the Listening Comprehension of Storybooks by Prekindergarten Children. Language, Speech, and Hearing Services in Schools, 44, 183-194. 
https://lshss.pubs.asha.org/article.aspx?articleid=1797332 https://doi.org/10.1044/0161-1461(2012/11-0073)

Romero-Godínez, E. (2012). Attention Model for First Graders Gifted Children. In G. Acle-Tomasini (Ed.), Resilience in Special Education: An Experience in Elementary School (pp. 353-393). GEDISA-UNAM-FES ZARAGOZA.

Rosales, R., Montero, D., \& Melgoza, J. (2005). Urban, Political and Social Diversity in Iztapalapa (pp. 19-85). México: Casa Abierta al Tiempo.

Schickedanz, J. A., \& Collins, M. F. (2012). For Young Children, Pictures in Storybooks Are Rarely Worth a Thousand Words. Reading Teacher, 65, 539-549.

https://ila.onlinelibrary.wiley.com/doi/full/10.1002/TRTR.01080

https://doi.org/10.1002/TRTR.01080

Schwarz, A. L., van Kleeck, A., Beaton, D., Horne, E., MacKenzie, H., \& Abdi, H. (2015). A Read-Aloud Storybook Selection System for Prereaders at the Preschool Language Level: A Pilot Study. Journal of Speech, Language, and Hearing Research, 58, 1273-1291. https://jslhr.pubs.asha.org/article.aspx?articleid=2341269 https://doi.org/10.1044/2015_JSLHR-L-15-0056

Secretaría de Educación Pública (2012). National Program to Strengthen Special Education and Educative Inclusion (pp. 12-30). México: SEP.

Teale, W. H. (2003). Reading Aloud to Young Children as a Classroom Instructional Activity: Insights from Research and Practice. In A. van Kleeck, S. A. Stahl, \& E. B. Bauer (Eds.), On Reading Books to Children: Parents and Teachers (pp. 109-133). Mahwah, NJ: Erlbaum.

UNESCO (2004). Education of Talented Children in Iberoamerica (pp. 129-142). Chile: Trineo.

United Nations Children's Fund (2006). The Exclusions of Elementary and Middle Education in Mexico City (p. 56).

http://www.unicef.org/mexico/spanish/mx_resources_exclusiones.pdf

Valdés Cuervo, A., Sánchez Escobedo, P., \& Yáñez Quijada, A. I. (2013). Estudiantes Mexicanos con Aptitudes Intelectuales Sobresalientes. Acta Colombiana de Psicología, 16, 25-33. http://www.scielo.org.co/pdf/acp/v16n1/v16n1a03.pdf

Van Horn, D., \& Kan, P. F. (2016). Fast Mapping by Bilingual Children: Storybooks and Cartoons. Child Language Teaching and Therapy, 32, 65-77.

http://journals.sagepub.com/doi/abs/10.1177/0265659015584975 https://doi.org/10.1177/0265659015584975

Wessels, S. (2014). Supporting English and Spanish Literacy through a Family Literacy Program. School Community Journal, 24, 147-164.

https://search.proquest.com/openview/69185934bff152ebdbd2b69473d71246/1?pq-orig $\underline{\text { site }=\text { gscholar } \& \mathrm{cbl}=28213}$

Zacatelco-Ramírez, F., Hernández-Castillo, R., \& Acle-Tomasini, G. (2012). Enriquecimiento de la creatividad escrita en alumnos sobresalientes de tercer ciclo de primaria. In G. Acle-Tomasini (Ed.), Resilience in Special Education. An Experience in Elementary School (pp. 433-463). Barcelona: GEDISA-UNAM-FES ZARAGOZA. 